Tropical Journal of Pharmaceutical Research March 2016; 15 (3): 497-506

ISSN: $1596-5996$ (print); 1596-9827 (electronic)

(C) Pharmacotherapy Group, Faculty of Pharmacy, University of Benin, Benin City, 300001 Nigeria.

All rights reserved.

Available online at http://www.tjpr.org

Original Research Article

http://dx.doi.org/10.4314/tjpr.v15i3.10

\title{
Determination of Phytochemical Compounds, and Tyrosinase Inhibitory and Antimicrobial Activities of Bioactive Compounds from Streblus ilicifolius (S Vidal) Corner
}

\author{
Sukanya Dej-adisai ${ }^{\star}$, Kedsaraporn Parndaeng and Chatchai \\ Wattanapiromsakul \\ Department of Pharmacognosy and Pharmaceutical Botany, Faculty of Pharmaceutical Sciences, Prince of Songkla University, \\ Hat-Yai, Songkhla 90112, Thailand
}

*For correspondence: Email: sukanya.d@psu.ac.th; Tel. \& Fax: +66-74-428220

Received: 15 March 2015

Revised accepted: 7 January 2016

\begin{abstract}
Purpose: To determine the phytochemical content, and tyrosinase inhibitory and antimicrobial activities of the wood from Streblus ilicifolius (S. Vidal) Corner

Methods: The dried wood of S. ilicifolius $(8.70 \mathrm{~kg}$ ) was extracted by maceration to give petroleum ether, ethyl acetate, ethanol and water extracts, respectively. Dopachrome method was used to determine antityrosinase activity. Agar disc diffusion and modified broth microdilution methods were used to determine antimicrobial activity. Chromatographic techniques were used for phytochemical investigation. The structures elucidation of isolated compounds were identified by physical properties and spectroscopic data including UV, IR, NMR and MS data and confirmed by comparison with previously reports.

Results: The ethanol extract exhibited tyrosinase inhibition and antimicrobial activity against the Grampositive bacteria, Staphylococcus epidermidis and S. aureus. Phytochemical investigation showed five compounds, namely, (E)-2,4-dihydroxy-3-(3,7-dimethyl-2,6-octadienyl) benzaldehyde (1), phydroxybenzoic acid methyl ester (2), umbelliferone (3), moracin M (4), trans-resveratrol (5). Compound 4 exhibited tyrosinase inhibition with half maximal inhibitory concentration $\left(I C_{50}\right)$ of $67.69 \mu \mathrm{g} / \mathrm{ml}$, while compound 1 displayed strong activity against $S$. epidermidis, S. aureus and methicillin-resistant $S$. aureus (MRSA) with minimum inhibitory concentration (MIC) of 8,4 and $8 \mu \mathrm{g} / \mathrm{ml}$, respectively and minimum bactericidal concentration (MBC) of 32, 16 and $64 \mu \mathrm{g} / \mathrm{ml}$, respectively.

Conclusion: This is the first report of the biological activities and phytochemical composition of $S$. ilicifolius and the results indicate the high potentials of the plant for commercial applications such as in facial whitening and anti-acne cream.
\end{abstract}

Keywords: Streblus ilicifolius, Moraceae, Tyrosinase inhibition, Antimicrobial, Anti-acne, Methicillinresistant Staphylococcus aureus

Tropical Journal of Pharmaceutical Research is indexed by Science Citation Index (SciSearch), Scopus, International Pharmaceutical Abstract, Chemical Abstracts, Embase, Index Copernicus, EBSCO, African Index Medicus, JournalSeek, Journal Citation Reports/Science Edition, Directory of Open Access Journals (DOAJ), African Journal Online, Bioline International, Open-J-Gate and Pharmacy Abstracts

\section{INTRODUCTION}

Melanin biosynthesis or melanogenesis initiated from L-tyrosine hydroxylated to L- dihydroxyphenylalanine (L-Dopa), then oxidation of L-Dopa to its corresponding o-dopaquinone, catalyzed by tyrosinase enzyme. o-Dopaquinone can be divided into two different types of reaction 
to produce eumelanin and pheomelanin $[1,2]$. The major function of melanin is to protect against ultraviolet (UV) radiation. However, excessive level of melanin or hyperpigmentation due to a darker or uneven of skin color, age spots, melasma and sites of actinic damage [1].

Tyrosinase inhibitors are becoming increasingly important contain in the treatment products of some dermatological disorders, associate with melanin hyperpigmentation and contain in cosmetic for skin whitening products [1]. Many problems from current whitening cosmetics such as ochronosis, allergic and irritant contact dermatitis, melanocyte toxicity and carcinogenicity [3] cause to find out the new natural whitening agents.

Pathogenic bacteria and dermatophyte fungus are a major cause of human skin disease. Moreover, some microorganisms can be stimulating the melanogenesis [4-7]. Antibiotics are the choice of treatment. However, the use of antibiotics may lead to drug resistance of many bacterial strains. Development of new antimicrobial compounds for resistant organisms is becoming critically important [8].

It is prompt search to find alternative agents from plants that have already been used topically to treat hyperpigmentation in skin of color $[1,3,9]$. The discovery of tyrosinase inhibition from medicinal plants is alternatives may provide leads for anti-pigmentation compounds and development to whitening and anti-browning agents.

In Thailand, there are many species of the plants in the genus Streblus, but only $S$. asper has been reported in traditional uses, and also their pharmacological activities and chemical constituents. However, in this study we have the focus on biological activities of $S$. ilicifolius wood extract. The extract showed the potential of antityrosinase and antimicrobial activities. The aim of this study was to evaluate some biological activities and chemical constitution of $S$. ilicifolius.

\section{EXPERIMENTAL}

\section{Plant material}

140 samples from 79 Thai medicinal plant extracts of Rajjaprabha Dam, Surat Thani Province were screened for antityrosinase activity.
S. ilicifolius (S. Vidal) Corner was collected from Rajjaprabha Dam, Surat Thani Province. The plant was identified by Ms. Nannapat Pattharahirantricin, botanist at Plant taxonomy Office of the Forest Herbarium, Department of National Parks, Wildlife and Plant Conservation, Bangkok, Thailand. The voucher specimen number of this plant was SKP 117190901 . It was collected at the Department of Pharmacognosy and Pharmaceutical Botany, Faculty of Pharmaceutical Sciences, Prince of Songkla University, Songkhla, Thailand.

\section{Extraction and isolation}

The dried wood of $S$. ilicifolius $(8.7 \mathrm{~kg})$ was chopped, ground and macerated with petroleum ether three times ( 3 days, each). The filtrates were pooled and evaporated under reduced pressure at temperature not exceeding $40{ }^{\circ} \mathrm{C}$. to yield a petroleum ether extract. Then the marc was extracted three times with ethyl acetate and ethanol (3 days, each). It follows an extraction with boiling water. Removal of the solvents gave an ethyl acetate, ethanol and $\mathrm{H}_{2} \mathrm{O}$ extract, respectively. The ethanol extract, showed the potential activities of antityrosinase and antimicrobial was selected for phytochemical investigation. The extract was fractionated by quick column chromatographic technique using a sintered glass-filter column of silica gel 60 (Merck). It was performed a gradient elution using mixtures of chloroform and ethyl acetate $(10: 0$ to $2: 8)$. Finally ethyl acetate was used to wash the column until the eluates were diluted and clear. The result was 13 fractions A-M. Repeated column chromatography of fraction $A$, gradient elution was performed using mixtures of hexane and ethyl acetate (9:1 to $1: 1)$, given to 15 subfractions. The subfraction A-7 was purified by repeat column chromatography to obtain compound 1. Repeated column chromatography of fraction $B$, seperation was carried out with gradient elution, using mixtures of hexane and ethyl acetate (7:3 to $1: 1)$, to give 8 subfractions. The subfraction B-2 was further fractionated by repeated column chromatography to obtain compound 2 and 3 . Repeated column chromatography of fraction $E$, gradient elution was performed using mixtures of chloroform and methanol (10:0 to 1:1). 12 subfractions were isolated. The subfraction E-8 showed the major spot was further fractionated by repeated column chromatography and crystallized (chloroformmethanol, 9:1) to obtain compound 4 and 5.

\section{General experimental procedures}

The structure of compounds was characterized by NMR spectroscopy and mass spectrometry. 
${ }^{1} \mathrm{H}$ and ${ }^{13} \mathrm{C}$ NMR, COSY, HMQC and HMBC spectra were recorded on Varian Unity Innova spectrometer operating at $500 \mathrm{MHz}$ for ${ }^{1} \mathrm{H}-\mathrm{NMR}$ and $125 \mathrm{MHz}$ for ${ }^{13} \mathrm{C}$-NMR and Bruker Avance III ( ${ }^{1} \mathrm{H}-\mathrm{NMR} 300 \mathrm{MHz}$ and ${ }^{13} \mathrm{C}-\mathrm{NMR} 75 \mathrm{MHz}$ ). Mass spectra were measured on Thermo Finnigan MAT $95 \mathrm{XL}$ mass spectrometer. The EI-MS of the compound was determined by GCMS analysis using an Agilent 7890A GC system interfaced to an Agilent 5975C MSD operating at $70 \mathrm{eV}$, ion source temperature $230^{\circ} \mathrm{C}$, interface temperature $280{ }^{\circ} \mathrm{C}$. A split injection $(1 \mu \mathrm{l}$ injection volume, split ratio, 20:1) at $260{ }^{\circ} \mathrm{C}$ injector temperature was utilized. A fused silica capillary column $5 \%$ phenyl $95 \%$ methyl polysiloxane (HP-5MS $30 \mathrm{~m} \times 250 \mu \mathrm{m} \times 0.25 \mu \mathrm{m}$, Agilent $\mathrm{J} \& \mathrm{~W}$, USA) was used. The temperature program was as follows: $1 \mathrm{~min}$ at $60^{\circ} \mathrm{C}$, then to $220^{\circ} \mathrm{C}$ at $10^{\circ} \mathrm{C} / \mathrm{min}$, then to $300^{\circ} \mathrm{C}$ at $4{ }^{\circ} \mathrm{C} / \mathrm{min}$, temperature kept at $300{ }^{\circ} \mathrm{C}$ for $10 \mathrm{~min}$. The carrier gas was helium 5.6 at a flow rate 1.2 $\mathrm{ml} / \mathrm{min}$. Data acquisition was performed with Agilent GC/MSD ChemStation Version E.02.00 for the mass scan range 40-700 u. Column chromatography was carried out using silica gel 60 (particle sized 0.040-0.063 mm). All reaction steps were checked by thin-layer chromatography (TLC). The analyses were performed on pre-coated silica gel 60 F254 plates. Spots on TLC were visualized under UV absorption (254 and $366 \mathrm{~nm}$ ). For this purpose, the plate was sprayed with anisaldehyde/ $\mathrm{H}_{2} \mathrm{SO}_{4}$ reagent followed by heating.

\section{Determination of antityrosinase activity}

Dopachrome method was used to determine antityrosinase activity, using L-Dopa as the substrate [10]. Dopachrome is one of the intermediate substrate in melanogenesis, this method used the L-Dopa as a substrate. The red color of dopachrome from the oxidation of LDopa can be detected by visible light at $492 \mathrm{~nm}$. Antityrosinase activity was performed in 96 well microplate. The samples were dissolved in DMSO to concentration of $200 \mu \mathrm{g} / \mathrm{ml}$. The first $20 \mu \mathrm{L}$ of the samples solution were mixed with phosphate buffer (pH 6.8) and $20 \mu \mathrm{L}$ of mushroom tyrosinase solution $(203.3 \mathrm{U} / \mathrm{ml})$ and incubated at $25^{\circ} \mathrm{C}$ for $10 \mathrm{~min}$. Then $20 \mu \mathrm{L}$ of LDopa $(0.85 \mathrm{mM})$ was added. The visible absorption was measured at $492 \mathrm{~nm}$. The solution was incubated at $25^{\circ} \mathrm{C}$ for $20 \mathrm{~min}$. After incubation the amount of dopachrome in the reaction was measured at $492 \mathrm{~nm}$ again. Tyrosinase inhibition ( $\mathrm{T}$ ) was calculated as in Equation 1.

$T(\%)=\{[(A-B)-(C-D)] /(A-B)\} 100$ where $A$ is the difference of optical density before and after incubation of control, $B$ is the difference of optical density before and after incubation of blank control, $\mathrm{C}$ is the difference of optical density before and after incubation of test sample, and $D$ is the difference of optical density before and after incubation of blank sample.

The concentration of the pure compound was measured which caused a $50 \%$ inhibition of tyrosinase activity $\left(\mathrm{IC}_{50}\right)$. Kojic acid and water extract of Artocarpus lakoocha wood were used as positive controls while DMSO was used as negative control.

\section{Determination of antimicrobial activity}

Microorganisms; Staphylococcus aureus (ATTC 25923), Staphylococcus epidermidis (TISTR 517), Propionibacterium acnes (DMST 14916) and Methicillin-resistant Staphylococcus aureus (MRSA 1350II 06) were alternate for gram positive bacteria. Escherichia coli ATCC35218 and Pseudomonas aeruginosa ATCC10145 were alternate for gram negative bacteria. Candida albicans (TISTR 5779) was alternate for yeast and Microsporum gypseum, Trichophyton rubrum and Trichophyton mentagrophytes were alternate for fungi. The preliminary screening of antimicrobial activity was used agar disc diffusion method [11]. The pure compounds were determined for minimum inhibitory concentration (MIC) and minimum bactericidal concentration (MBC) in 96 well microplate by modified broth microdilution method [12,13]. Oxacillin, norfloxacin, amphotericin B and ketoconazole were used as positive controls for gram positive bacteria (except MRSA using vancomycin), gram negative bacteria, yeast and fungi, respectively.

\section{RESULTS}

\section{Antityrosinase activity}

From 140 samples, S. ilicifolius ethanol wood extract showed the highest activity of antityrosinase with $69.05 \pm 5.00 \%$.

\section{Antimicrobial activity}

The ethanol extract of the wood from S. ilicifolius showed the potential antibacterial effects against $S$. epidermidis and $S$. aureus with inhibition zone $9.25 \pm 0.56$ and $8.47 \pm 0.31 \mathrm{~mm}$, respectively (Table 1). 


\section{Extraction of S. ilicifolius wood}

The dry weight, \% yield (base on dried wood) and $\%$ tyrosinase inhibition of these crude extracts from the wood of $S$. ilicifolius are shown in Table 2. The ethanol extract was the most interesting fraction because of the potential effects of antityrosinase and antimicrobial activities. So it was selected for isolation of the chemical constituents.

\section{Structure of isolated compounds}

Five pure compounds were isolated from ethanol extract of $S$. ilicifolius (Figure 1). The structures of the isolated compounds, identified by physical properties and spectroscopic data, including UV, IR, NMR and MS data and confirmed by comparison with previously reports are as (E)2,4-dihydroxy-3-(3,7-dimethyl-2,6-octadienyl) benzaldehyde (1) [14], p-hydroxy benzoic acid methyl ester (2) [15], umbelliferone (3) [16], moracin M (4) [17] and trans-resveratrol (5) [18]. Their spectral data are given as follow:
(E)-2,4-Dihydroxy-3-(3,7-dimethyl-2,6octadienyl) benzaldehyde (Compound 1); $\mathrm{C}_{17} \mathrm{H}_{22} \mathrm{O}_{3}$

Compound 1 was obtained as colorless needles, soluble in chloroform. The melting point showed at $72.33 \stackrel{\circ}{\circ} \mathrm{C}$ (Differential scanning calorimeter). The El mass spectrum of compound 1 exhibited a molecular ion at $274 \mathrm{~m} / \mathrm{z}$, consistent with a molecular formula of $\mathrm{C}_{17} \mathrm{H}_{22} \mathrm{O}_{3}$, confirmed by HREIMS which showed a molecular ion peak at $\mathrm{m} / \mathrm{z}$ 274.1560 calcd. for $\mathrm{C}_{17} \mathrm{H}_{22} \mathrm{O}_{3}, 274.1566$. The UV spectrum in chloroform demonstrated absorption maximum in chloroform at $\lambda_{\max }$ (absorbance) 228 (0.180), 242 (0.235), 286(0.593) and 396(0.007) $\mathrm{nm}$. The IR spectrum exhibited maximum absorption bands at 3401, 2923, 2851 and 1622 $\mathrm{cm}^{-1}$. The ${ }^{1} \mathrm{H}$ and ${ }^{13} \mathrm{C}$ NMR spectra of compound 1 are showed as:

${ }^{1} \mathrm{H}$ NMR (500 MHz, $\left.\mathrm{CDCl}_{3}\right): 1.57\left(3 \mathrm{H}, \mathrm{s}, \mathrm{H}-9^{\prime}\right)$, $1.65\left(3 \mathrm{H}, \mathrm{s}, \mathrm{H}-10^{\prime}\right), 1.80\left(3 \mathrm{H}, \mathrm{s}, \mathrm{H}-4^{\prime}\right), 2.06(4 \mathrm{H}$, m, H-5', H-6'), $3.43\left(2 \mathrm{H}, \mathrm{d}, \mathrm{J}=7.3 \mathrm{~Hz}, \mathrm{H}-1^{\prime}\right), 5.02$ $\left(1 \mathrm{H}, \mathrm{m}, \mathrm{H}-7^{\prime}\right), 5.24\left(1 \mathrm{H}, \mathrm{tq}, \mathrm{J}=7.3,1.1 \mathrm{~Hz}, \mathrm{H}-2^{\prime}\right)$, $6.28(1 \mathrm{H}, \mathrm{s}, 4-\mathrm{OH}), 6.46(1 \mathrm{H}, \mathrm{d}, \mathrm{J}=8.4 \mathrm{~Hz}, \mathrm{H}-5)$, $7.28(1 \mathrm{H}, \mathrm{d}, \mathrm{J}=8.4 \mathrm{~Hz}, \mathrm{H}-6), 9.66(1 \mathrm{H}, \mathrm{s}, 1-\mathrm{COH})$, $11.75(1 \mathrm{H}, \mathrm{s}, 2-\mathrm{OH})$;

Table 1: Antimicrobial activity of $S$. ilicifolius solvent extract

\begin{tabular}{|c|c|c|c|c|c|}
\hline \multirow[t]{2}{*}{ Microorganism } & \multicolumn{4}{|c|}{ Diameter $^{\mathrm{a}}$ of inhibition zone $(\mathrm{mm})$} & \multirow[t]{2}{*}{ Positive control } \\
\hline & Pet. ether & EtOAC & $\mathrm{EtOH}$ & Water & \\
\hline \multicolumn{6}{|c|}{ Gram-positive bacteria } \\
\hline S. epidermidis & - & - & $9.25 \pm 0.56$ & - & $28.01 \pm 0.55^{\mathrm{b}}$ \\
\hline S. aureus & - & - & $8.47 \pm 0.31$ & - & $18.73 \pm 0.40^{\mathrm{b}}$ \\
\hline P. acnes & - & - & & - & $37.83 \pm 2.84^{\mathrm{b}}$ \\
\hline \multicolumn{6}{|c|}{ Gram-negative bacteria } \\
\hline E. coli & - & - & - & - & $28.42 \pm 3.42^{\mathrm{c}}$ \\
\hline $\begin{array}{l}\text { P. aeruginosa } \\
\text { Yeast }\end{array}$ & - & - & - & - & $29.75 \pm 0.21^{\mathrm{c}}$ \\
\hline & \multicolumn{4}{|c|}{ Fungi } & $15.77 \pm 1.13^{d}$ \\
\hline M. gypseum & - & - & - & - & $20.97 \pm 1.25^{\mathrm{e}}$ \\
\hline T. rubrum & - & - & - & - & $38.50 \pm 2.12^{\mathrm{e}}$ \\
\hline T. mentagrophyts & - & - & - & - & $31.01 \pm 1.43^{\mathrm{e}}$ \\
\hline
\end{tabular}

Table 2: Yield and tyrosinase inhibitory activity of $S$. ilicifolius crude extract (at final concentration $20 \mu \mathrm{g} / \mathrm{ml}$ )

\begin{tabular}{|c|c|c|c|}
\hline Crude extract & Dry weight (g) & Yield (\%) & Tyrosinase inhibition (\%) \\
\hline $\begin{array}{l}\text { Petroleum ether } \\
\text { Ethyl acetate } \\
\text { Ethanol } \\
\mathrm{H}_{2} \mathrm{O} \\
\text { Kojic acid } \\
\text { Artocarpus lakoocha }^{\mathbf{P}}\end{array}$ & $\begin{array}{c}9.75 \\
23.21 \\
109.78 \\
103.96 \\
- \\
- \\
\end{array}$ & $\begin{array}{l}0.11 \\
0.27 \\
1.26 \\
1.19 \\
- \\
- \\
\end{array}$ & $\begin{array}{c}2.45 \pm 5.90 \\
24.38 \pm 1.04 \\
75.52 \pm 5.42 \\
3.17 \pm 5.24 \\
80.86 \pm 2.62 \\
87.62 \pm 1.52 \\
\end{array}$ \\
\hline
\end{tabular}




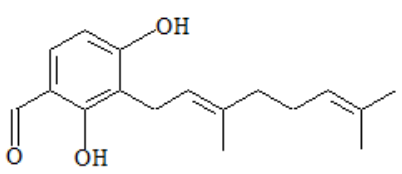

(E)-2,4-Dihydroxy-3-(3,7-dimethyl-2,6-octadienyl) benzaldehyde (1)<smiles>COC(=O)c1ccc(O)cc1</smiles>

p-hydroxybenzoic acid methyl ester (2)<smiles>COc1cc(O)cc(-c2cc3ccc(O)cc3o2)c1</smiles>

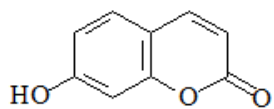

umbelliferone (3)

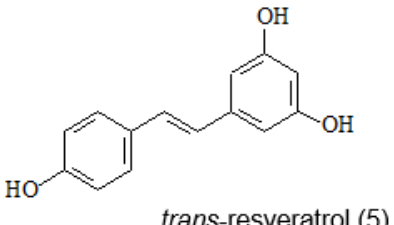

Figure 1: Pure compounds isolated from ethanol extract of Streblus ilicifolius wood

${ }^{13} \mathrm{C}$ NMR (125 MHz, $\left.\mathrm{CDCl}_{3}\right): 16.23$ (C-16'), 17.69 (C-9'), 21.33 (C-1'), 25.65 (C-10'), 26.26 (C-6'), 39.67 (C-5'), 109.04 (C-5), 113.50 (C-3), 115.02 (C-1), 120.55 (C-2'), 123.60 (C-7'), 132.16 (C-8'), 133.50 (C-6), 140.06 (C-3'), 161.65 (C-4), 162.70 (C-2), 194.63 (1-COH).

\section{p-Hydroxybenzoic acid methyl ester (Compound 2); $\mathrm{C}_{8} \mathrm{H}_{8} \mathrm{O}_{3}$}

The compound 2 was obtained as a colorless needles, soluble in methanol and dimethyl sulfoxide. The melting point showed at $118{ }^{\circ} \mathrm{C}$. The \% abundance GC-MS of compound 2 exhibited a molecular ion at $152 \mathrm{~m} / \mathrm{z}$, consistent with a molecular formula of $\mathrm{C}_{9} \mathrm{H}_{6} \mathrm{O}_{3}$. The UV spectrum in methanol demonstrated absorption maximum in methanol at $\lambda_{\max }$ (absorbance) 255 $(0.837)$ and $314(0.121) \mathrm{nm}$. The IR spectrum exhibited maximum absorption bands at 3355 , 1681, 1609, 1585 and $1513 \mathrm{~cm}^{-1}$. The ${ }^{1} \mathrm{H}$ and ${ }^{13} \mathrm{C}$ NMR spectra of compound 2 are showed as:

${ }^{1} \mathrm{H}-\mathrm{NMR}\left(300 \mathrm{MHz}\right.$, DMSO- $\left.\mathbf{d}_{6}\right): 3.78(3 \mathrm{H}, \mathrm{s}, 7-$ $\left.\mathrm{OCH}_{3}\right), 6.84(2 \mathrm{H}, \mathrm{d}, \mathrm{J}=8.70 \mathrm{~Hz}, \mathrm{H}-2, \mathrm{H}-6), 7.80$ $(2 \mathrm{H}, \mathrm{d}, \mathrm{J}=8.68 \mathrm{~Hz} \mathrm{H}-3, \mathrm{H}-5),, 10.34(1 \mathrm{H}$, brs, 4$\mathrm{OH}$ );

${ }^{13}$ C-NMR (75 MHz, DMSO- $\left.d_{6}\right): 52.06\left(7-\mathrm{OCH}_{3}\right)$, 115.78 (C-2, C-6), 120.68 (C-1), 131.86 (C-3, C5), 162.39 (C-4), 166.50 (C-7).

\section{Umbelliferone (Compound 3); $\mathrm{C}_{9} \mathrm{H}_{6} \mathrm{O}_{3}$}

The compound 3 was obtained as a yellowish crystalline, soluble in methanol and dimethyl sulfoxide. The melting point showed at $230^{\circ} \mathrm{C}$. It gave a molecular ion at $162 \mathrm{~m} / \mathrm{z}$ in the \% abundance GC-MS, suggesting a tentative molecular formula of $\mathrm{C}_{9} \mathrm{H}_{6} \mathrm{O}_{3}$. The UV spectrum in methanol displayed absorptions maximum in methanol at $\lambda_{\max } 216,258$ and $332 \mathrm{~nm}$. The ${ }^{1} \mathrm{H}$ and ${ }^{13} \mathrm{C}$ NMR spectra of compound 3 are showed as:

${ }^{1} \mathrm{H}-\mathrm{NMR}\left(300 \mathrm{MHz}\right.$, DMSO- $\left.d_{6}\right): 6.19(1 \mathrm{H}, \mathrm{d}, J=$ $9.45 \mathrm{~Hz}, \mathrm{H}-3), 6.71(1 \mathrm{H}, \mathrm{d}, \mathrm{J}=2.28 \mathrm{~Hz}, \mathrm{H}-8), 6.78$ $(1 \mathrm{H}, \mathrm{dd}, \mathrm{J}=8.49,2.31 \mathrm{~Hz}, \mathrm{H}-6), 7.52(1 \mathrm{H}, \mathrm{d}$, $J=8.49 \mathrm{~Hz}, \mathrm{H}-5), 7.93(1 \mathrm{H}, \mathrm{d}, \mathrm{J}=9.48 \mathrm{~Hz}, \mathrm{H}-4)$;

${ }^{13} \mathrm{C}-\mathrm{NMR}\left(75 \mathrm{MHz}\right.$, DMSO- $\left.d_{6}\right): 102.61$ (C-8), 111.66 (C-4a), 111.77 (C-3), 113.62 (C-6), 130.16 (C-5), $145.01 \quad(\mathrm{C}-4), 155.97$ (C-8a), 160.91 (C-7), 161.89 (C-2).

\section{Moracin M (Compound 4); $\mathrm{C}_{14} \mathrm{H}_{10} \mathrm{O}_{4}$}

The compound 4 was obtained as a cream needles, soluble in methanol and dimethyl sulfoxide. The melting point showed at $270{ }^{\circ} \mathrm{C}$. It gave a molecular ion at $242 \mathrm{~m} / \mathrm{z}$ in the El mass spectrum, corresponding to $\mathrm{C}_{14} \mathrm{H}_{10} \mathrm{O}_{4}$. The UV spectrum in methanol showed absorptions at $\lambda_{\max }$ (absorbance) 216 (0.863), 315 (0.938) and $328(0.796) \mathrm{nm}$. The IR spectrum showed the absorption bands at $3521,3328,1613,1436$, 1292 and $1141 \mathrm{~cm}^{-1}$. The ${ }^{1} \mathrm{H}$ and ${ }^{13} \mathrm{C}$ NMR spectra of compound 4 are showed as:

${ }^{1} \mathrm{H}-\mathrm{NMR}\left(500 \mathrm{MHz}\right.$, DMSO- $\left.d_{6}\right): 6.20(1 \mathrm{H}, \mathrm{t}$, $\left.J=2.05 \mathrm{~Hz}, \mathrm{H}-4^{\prime}\right), 6.67\left(2 \mathrm{H}, \mathrm{d}, \mathrm{J}=2.05 \mathrm{~Hz}, \mathrm{H}-2^{\prime}\right.$, $\left.\mathrm{H}-6^{\prime}\right), 6.72(1 \mathrm{H}, \mathrm{dd}, \mathrm{J}=8.46,2.06 \mathrm{~Hz}, \mathrm{H}-5), 6.91$ $(1 \mathrm{H}$, ddd, J=2.06, $0.91 \mathrm{~Hz}, \mathrm{H}-7), 7.05(1 \mathrm{H}, \mathrm{d}$, $J=0.91 \mathrm{~Hz}, \mathrm{H}-3), 7.371 \mathrm{H}, \mathrm{d}, J=8.25 \mathrm{~Hz}, \mathrm{H}-4)$, $9.39(2 \mathrm{H}$, brs, 3'-OH, 5'-OH), $9.95(1 \mathrm{H}$, brs, 6$\mathrm{OH}$;

${ }^{13}$ C-NMR (125 MHz, DMSO- $d_{6}$ ): 97.62 (C-7), 101.69 (C-3), 102.47 (C-2', C-6'), 102.81 (C-4'), 112.61 (C-5), 120.94 (C-3a), 121.26 (C-4), 
Table 3: Tyrosinase inhibitory activity $\left(\mathrm{IC}_{50}\right)$ of pure compounds isolated from S. ilicifolius

\begin{tabular}{lc}
\hline Compound & IC $_{50}(\boldsymbol{\mu g} / \mathbf{m l})$ \\
\hline (E)-2,4-Dihydroxy-3-(3,7-dimethyl-2,6-octadienyl) benzaldehyde (1) & $>200$ \\
p-Hydroxybenzoic acid methyl ester (2) & $>200$ \\
Umbelliferone (3) & NT \\
Moracin M (4) & 67.69 \\
Trans-resveratrol (5) & NT \\
Kojic acid & 38.67 \\
Artocarpus lakoochaWP $^{\text {WP }}$ & 8.73 \\
\hline W
\end{tabular}

${ }^{W}=$ water $_{\text {wood extract }}{ }^{P}=$ positive control; $N T=$ not tested

Table 4: $\quad$ MIC and MBC of isolated compounds against $S$. epidermidis, S. aureus and MRSA

\begin{tabular}{|c|c|c|c|c|c|c|}
\hline \multirow{2}{*}{ Compound } & \multicolumn{2}{|c|}{ S. epidermidis } & \multicolumn{2}{|c|}{ S. aureus } & \multicolumn{2}{|c|}{ MRSA } \\
\hline & \multicolumn{2}{|c|}{$(\mu g / m l)$} & \multicolumn{2}{|c|}{$(\mu g / m l)$} & \multicolumn{2}{|c|}{$(\mu g / m I)$} \\
\hline 1 & 8 & 32 & 4 & 16 & 8 & 64 \\
\hline 2 & 256 & $>256$ & $>256$ & $>256$ & $>256$ & $>256$ \\
\hline 3 & NT & NT & NT & NT & NT & NT \\
\hline 4 & 64 & $>256$ & 128 & $>256$ & 64 & $>256$ \\
\hline 5 & NT & NT & NT & NT & NT & NT \\
\hline Oxacillin $^{P}$ & 0.5 & - & 0.25 & - & - & - \\
\hline Vancomycin $^{P}$ & - & - & - & - & 0.5 & - \\
\hline
\end{tabular}

$N T=$ not tested $;^{P}=$ positive control; Oxacillin for S. epidermidis and S. aureus, Vancomycin for MRSA

$131.82\left(\mathrm{C}-1^{\prime}\right), 154.13(\mathrm{C}-2), 155.42$ (C-7a), 155.88 (C-6), 158.94 (C-3', C-5').

trans-Resveratrol (Compound 5); $\mathrm{C}_{14} \mathrm{H}_{12} \mathrm{O}_{3}$

The compound 5 was obtained as a brownish crystalline, soluble in methanol and dimethyl sulfoxide. The melting point showed at $265^{\circ} \mathrm{C}$. It gave a molecular ion at $228 \mathrm{~m} / \mathrm{z}$ in the \% abundance GC-MS, suggesting a tentative molecular formula of $\mathrm{C}_{14} \mathrm{H}_{12} \mathrm{O}_{3}$. The UV spectrum in methanol, showed absorptions at $\lambda_{\max }$ (absorbance) 207 (0.647), 315 (0.531) and 328 $(0.450) \mathrm{nm}$. The IR spectrum exhibited maximum absorption bands at 3234, 1618, 1578, 1508 and $1485 \mathrm{~cm}^{-1}$. The ${ }^{1} \mathrm{H}$ and ${ }^{13} \mathrm{C}$ NMR spectra of compound 5 are showed as:

${ }^{1} \mathrm{H}-\mathrm{NMR}\left(300 \mathrm{MHz}\right.$, DMSO- $\left.\boldsymbol{d}_{6}\right): 6.10(1 \mathrm{H}$, brs, $J=2.10 \mathrm{~Hz}, \mathrm{H}-4), 6.37(2 \mathrm{H}, \mathrm{d}, \mathrm{J}=2.13 \mathrm{~Hz}, \mathrm{H}-2, \mathrm{H}-$ 6), $6.74\left(2 \mathrm{H}, \mathrm{d}, \mathrm{J}=8.58 \mathrm{~Hz}, \mathrm{H}-3^{\prime}, \mathrm{H}-5^{\prime}\right), 6.80(1 \mathrm{H}$, $\mathrm{d}, J=16.22 \mathrm{~Hz}, \mathrm{H}-\alpha), 6.93(1 \mathrm{H}, \mathrm{d}, J=16.35 \mathrm{~Hz}$, H- $\left.\alpha^{\prime}\right), 7.38\left(2 \mathrm{H}, \mathrm{d}, \mathrm{J}=8.55 \mathrm{~Hz}, \mathrm{H}-2^{\prime}, \mathrm{H}-6^{\prime}\right), 9.20$ (2H, brs, 3-OH, 5-OH), $9.56\left(1 \mathrm{H}\right.$, brs, $\left.4^{\prime}-\mathrm{OH}\right)$;

${ }^{13}$ C-NMR (75 MHz, DMSO- $\boldsymbol{d}_{6}$ ): 102.19 (C-4), 104.72 (C-2, C-6), 115.94 (C-3', C-5'), 126.07

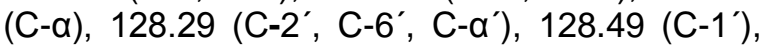
139.69 (C-1), 157.65 (C-4'), 158.93 (C-3, C-5).

GC-MS (El): $m / z(\%)=228.1\left[\mathrm{M}^{+}\right](100), 211.1$ (10), 181.1 (17), 157.1 (12), 115.0 (9), 44.0(12).

\section{Antityrosinase activity of isolated compounds}

Determination of tyrosinase inhibitory activity by dopachrome method of isolated compounds was showed in Table 3.

\section{Antimicrobial activity of isolated compounds}

From the screening of antimicrobial activity, $S$. ilicifolius ethanol extract displayed an inhibition zone against $S$. aureus and $S$. epidermidis. MIC and MBC of isolated compounds were determined with $S$. epidermidis, $S$. aureus and methicillin-resistant $S$. aureus (MRSA). The MIC and MBC values of isolated compounds are showed in Table 4.

\section{DISCUSSION}

Five pure compounds were isolated from $S$. ilicifolius for the first time although all of them are known compounds. Compound 1 and 2 were inactive with antityrosinase activity. While, compound 4 was found to exhibit a high antityrosinase activity. The hydroxyl group at the 6 position of moracin $\mathrm{M}$ has been reported that it might mediate the inhibitory activity [19]. Moracin $M$ is 2-arylbenzofuran, the hydroxyl group at the 6 position might mediate the inhibitory activity, compared with two 2arylbenzofurans; moracin $\mathrm{N}$ and moracin $\mathrm{O}$ 
(Figure 2). Moracin $\mathrm{N}$ and moracin $\mathrm{O}$ belong to isoprenyl-substituted 2-arylbenzofuran which showed the activity against tyrosinase with $\mathrm{IC}_{50}$ $30.52 \mu \mathrm{M}$ and $93.58 \mu \mathrm{M}$, respectively. In moracin $\mathrm{O}$, the isoprenyl group forms a five-membered ring with the hydroxyl group at the 6 position, whereas in moracin $\mathrm{N}$, the isoprenyl group remains intact which might contribute to its higher tyrosinase inhibitory activity than moracin O [19].

The activity of tyrosinase inhibitors are classified into four types, including competitive inhibitors, uncompetitive inhibitors, mixed type (competitive/ uncompetitive) inhibitors, and non-competitive inhibitors [26]. Resveratrol is a polyphenolic phytoalexin that belongs to the stilbenes, which have demonstrated potent tyrosinase inhibitory activity [27]. This substance acts as a "suicide substrate" for tyrosinase [28]. While, umbelliferone is a coumarin analog with hydroxyl group at $\mathrm{C} 7$ could be competitive potent tyrosinase inhibitory activity like the other coumarin, esculetin [29]. Moreover moracin M, the arylbenzofuran showed competitive potent tyrosinase inhibitory activity [30].

(E)-2,4-Dihydroxy-3-(3,7-dimethyl-2,6-octadienyl) benzaldehyde (1) showed strong inhibitory effect against $S$. epidermidis, $S$. aureus and MRSA. Friedman et al [25]. reported that 2, 3dihydroxybenzaldehyde was highly active against four bacteria (Campylobacter jejuni, Escherichia coli, Listeria monocytogenes and Salmonella enterica) because hydroxyl group at the position
2 and 3 enhance the antimicrobial activities of benzaldehyde. Then, hydroxyl group at the position 2 and 3 of 2, 3- dihydroxy-4-geranyl benzaldehyde might mediate the inhibitory activity.

Moracin M (4) is the arylbenzofuran, showed weak inhibitory effect against, $S$. epidermidis, $S$. aureus and MRSA. Mazimba et al [30] reported moracin $\mathrm{M}$ against $S$. aureus (MIC $62.5 \mu \mathrm{g} / \mathrm{mL}$ ), B. subtilis (MIC $31.25 \mu \mathrm{g} / \mathrm{mL}$ ), M. flavus (MIC $125 \mu \mathrm{g} / \mathrm{mL}$ ), S. faecalis (MIC $62.5 \mu \mathrm{g} / \mathrm{mL}$ ), $S$. abony (MIC $62.5 \mu \mathrm{g} / \mathrm{mL}$ ) and $P$. aeruginosa (MIC $125 \mu \mathrm{g} / \mathrm{mL}$ ). Moreover, Kuetu et al [32] reported that all tested microbial species (Gram-positive, Gram-negative bacteria and fungi) were inhibited by non-prenylated arylbenzofurans; moracin $M$ and moracin Q (Figure 4) weaker than prenylated arylbenzofurans; moracin $\mathrm{T}$ and moracin $\mathrm{C}$ (Figure 4) because prenyl increases the antimicrobial activity of arylbenzofurans.

p-hydroxybenzoic acid methyl ester (2) showed very low MIC against $S$. epidermidis. It is one of a homologous series of parabens used to exert antimicrobial affect especially, useful against molds and yeasts. It againsts $A$. oryzae (MIC 600 $\mu \mathrm{g} / \mathrm{mL}$ ), T. lignorum (MIC $250 \mu \mathrm{g} / \mathrm{mL}$ ), S. lutea (MIC $4000 \mu \mathrm{g} / \mathrm{mL}$ ), E. cloacae (MIC 1000 $\mu \mathrm{g} / \mathrm{mL}$ ), P. vulgaris (MIC $2000 \mu \mathrm{g} / \mathrm{mL}$ ) (Kibbe, 2000), E. coli (wild type) (MIC $1400 \mu \mathrm{g} / \mathrm{mL}$ ), $E$. coli (envelope mutant) (MIC $1000 \mu \mathrm{g} / \mathrm{mL}$ ), $P$. aeruginosa (wild-type) (MIC $1800 \mu \mathrm{g} / \mathrm{mL}$ ) and $P$. aeruginosa (envelope mutant) (MIC $1000 \mu \mathrm{g} / \mathrm{mL}$ ) [33]. $\overbrace{6}^{5}{ }_{7 a}^{3 a^{3}}$

Moracin M<smiles>CC(C)=CCc1cc2cc(-c3cc(O)cc(O)c3)oc2cc1O</smiles>

Moracin $\mathrm{N}$

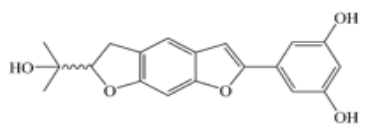

Moracin O

Figure 2: Structure of moracin $\mathrm{M}$, moracin $\mathrm{N}$ and moracin $\mathrm{O}$<smiles>O=C1CCC2CCC(O)C(O)C2C1</smiles>

Umbelliferone<smiles>O=c1ccc2cc(O)c(O)cc2o1</smiles>

Esculetin<smiles>O=c1ccc2ccc(O)c(O)c2o1</smiles>

Daphnetin<smiles>COc1ccc2ccc(=O)oc2c1O</smiles>

Daphnin|

Figure 3: Structure of umbelliferone, esculetin, daphnetin and daphnin 
$\overbrace{6}^{5}$

Moracin M

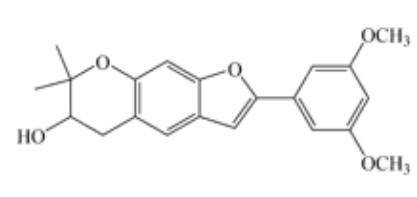

Moracin Q

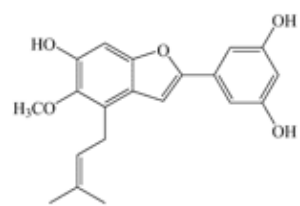

Moracin T

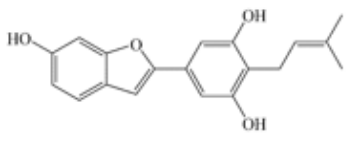

Moracin C

Figure 4: Structure of moracin $M, Q, T$ and $C$<smiles>O=c1ccc2ccc(O)cc2o1</smiles>

Umbelliferone<smiles>COc1c(O)ccc2ccc(=O)oc12</smiles>

Rhodonetin glucoside<smiles>COc1ccc2ccc(=O)oc2c1OC</smiles>

Rhodonin<smiles>O=c1ccc2ccc(OC3CCCCC3)c(O)c2o1</smiles>

Daphnin<smiles>COc1ccc(Cl)c2ccc(=O)oc12</smiles>

Rhodonetin|<smiles>O=c1ccc2ccc(O)c(O)c2o1</smiles>

Daphnetin

Figure 5: The structure of umbelliferone, rhodonetin, rhodonetin glucoside, rhodonin, daphnin and daphnetin

Some of the isolated compounds; umbelliferone (3) and trans-resveratrol (5) did not test because they have trace amount. However, they have been reported of anti-microbial activity.

Resveratrol showed activity against Grampositive bacteria higher than Gram- negative bacteria. It had the highest activity against Bacillus cereus followed by Staphylococcus aureus, MRSA and Enterococcus faecalis [34]. Morever, Kukric and Topalic-Trivunovic [35] reported that trans-resveratrol showed antimicrobial activity against test organisms ( $E$. coli, B. subtilis, Straphylococcus sp. and S. lutea) higher than cis-resveratrol. In addition, transresveratrol displayed potent antifungal activity against human pathogenic fungi $(C$. albicans, $S$. cerevisiae and T. beigelii with MIC 10, 10-20 and $10 \mu \mathrm{g} / \mathrm{mL}$ ), respectively [36].

Umbelliferone (Figure 5), which has a free hydroxyl at the position 7 , did not possess good antibacterial activity while, daphnetin which has free hydroxyl at the position 7 and 8 , is the most active compound out of all the coumarins tested. Moreover, daphnin and rhodonetin which has free hydroxyl at the position 8 , showed better activity than rhodonetin glucoside which the glycoside at the position 8 and rhodonin which methoxyl at the position 8. From the data concluded that coumarins with free hydroxyl at the position 8 possess better antibacterial activity [37].
However, these results will be useful for further study for pharmaceutical cosmetics or application for skin treatment of hyperpigmentation and infectious diseases such as the formulations of cream, serum, mask and so on.

\section{CONCLUSION}

Five pure compounds were isolated from the wood of $S$. ilicifolius. This is the first report on the biological activities and phytochemical profile of S. ilicifolius. Also, (E)-2,4-Dihydroxy-3-(3,7dimethyl-2,6-octadienyl) benzaldehyde from natural products, which has been investigated here for the first time, shows good antimicrobial activity. Moracin $\mathrm{M}$ has antityrosinase activity. However, further studies ascertain the actual therapeutic potentials of the compounds in the management of infectious diseases and hyperpigmentation.

\section{ACKNOWLEDGEMENT}

This research was supported by Plant Genetic Conservation Project under The Royal Initiative of Her Royal Highness Princess Maha Chakri Sirindhorn (RSPG project) and Prince of Songkla University, Thailand. 


\section{REFERENCES}

1. Kim YJ, Uyama H. Tyrosinase inhibitors from natural and synthetic sources: structure, inhibition mechanism and perspective for the future. Cell Mol Life Sci 2005; 62. 1707-1723.

2. Slominski A, Tobin DJ, Shibahara S, Wortsman J. Melanin pigmentation in mammalian skin and its hormonal regulation. Physiol Rev 2004; 84: 1155-1228.

3. Konda S, Geria AN, Halder RM. New horizons in treating disorders of hyperpigmentation in skin of color. Semin Cutan Med Surg 2012; 31: 133-139.

4. Athikomkulchai $S$, Watthanachaiyingcharoen $R$, Tunvichien $S$, Vayumhasuwan $P$, Karnsomkiet $P$, SaeJong $P$, Ruangrungsi $N$. The development of anti-acne products from Eucalyptus globulus and Psidium guajava oil. J Health Res 2008; 22: 109-113.

5. Kumar GS, Jayaveera KN, Kumar CKA, Sanjay UP, Swamy BMV, Kumar DVK. Antimicrobial effects of Indian medicinal plants against acne inducing bacteria. Trop J Pharm Res 2007; 6: 717-723.

6. Machado AP, Vivi VK, Tavares JR, Filho FJG, Fischman $O$. Antibiosis and dark-pigments secretion by the phytopathogenic and environmental fungal species after interaction in vitro with a Bacillus subtilis isolate. Brazilian Arch Biol Technol 2010; 53: 997-1004.

7. Petit L, Piérard GE. Skin-lightening products revisited. Int J Cosmetic Sci 2003; 25: 169-181.

8. Devienne KF, Raddi G, Coelho RG, Vilegas W. Structure-antimicrobial activity of some natural isocoumarins and their analogues. Phytomed 2005; 12 : 378-381.

9. Kakita LS, Lowe NJ. Azelaic acid and glycolic acid combination therapy for facial hyperpigmentation in darker-skinned patients: a clinical comparison with hydroquinone. Clin Ther 1998; 20: 960-970.

10. Sritularak B, De-Eknamkul W, Likhitwitayawuid $K$. Tyrosinase inhibitors from Artocarpus lakoocha. Thai $J$ Pharm Sci 1998; 22: 149-155.

11. Lorian V. Antibiotics in laboratory medicine, 5th ed., USA: Lippincott Williams \& Wilkins; 2005.

12. Clinical and Laboratory Standards Institute (CLSI), Methods for dilution antimicrobial susceptibility testes for bacterial that grow aerobically; approved standards, 7th ed. USA: Clinical and Laboratory Standards Institute, Wayne, Pennsylvania; 2006.

13. Kummee $S$, Intaraksa N. Antimicrobial activity of Desmos chinensis leaf and Maclura cochinchinensis wood extract. Songklanakarin J Sci Technol 2008; 30: 635-639.

14. Saimoto H, Kita K, Yabu Y, Yamamoto M. Novel dihydroxybenzene derivatives and antiprotozoal agent comprising same as active ingredient. Arigen Pharmaceuticals, Inc. W02012060387 A1. 2012. (Patent).

15. Chan LW, Kurup TR, Muthaiah A, Thenmozhiyal JC. Interaction of p-hydroxybenzoic esters with betacyclodextrin. Int J Pharm 2000; 195: 71-79.
16. Yan J, Tong S, Sheng L, Lou J, Liq J. Preparative isolation and purification of two coumarins from Edgeworthia chrysantha Lindl. by high speed countercurrent chromatography. Chromatogr R T 2006; 29: 1307-1315.

17. Zhang $M$, Chen M, Zhang HQ, Sun S, Xia B, Wu FH. In vivo hypoglycemic effects of phenolics from the root bark of Morus alba. Fitoterapia 2009; 80: 475-477.

18. Commodari F, Khiat A, Ibrahimi S, Brizius AR, Kalkstein $N$. Comparison of the phytoestrogen trans-resveratrol (3,4',5-trihydroxystilbene) structures from $x$-ray diffraction and solution NMR. Magn Reson Chem 2005; 43: 567-572.

19. Zheng ZP, Cheng KW, Zhu Q, Wang XC, Lin ZX, Wang $M$. Tyrosinase inhibitory constituents from the roots of Morus nigra: a structure-activity relationship study. J Agr Food Chem 2010; 58: 5368-5373.

20. Sritularak B. Chemical constituents of Artocarpus lakoocha and A. gomezianus, Master's thesis, Department of Pharmacognosy, Gradute School, Chulalongkorn University, Bangkok., 1998.

21. Sollai $F$, Zucca $P$, Sanjust $E$, Steri $D$, Rescigno $A$. Umbelliferone and esculetin: inhibitors or substrates for polyphenol oxidases? Biol Pharm Bull 2008; 31: $2187-$ 2193.

22. Masamoto $Y$, Murata $Y$, Baba K, Shimoishi $Y$, Tada $M$, Takahata K. Inhibitory effects of esculetin on melanin biosynthesis. Biol Pharm Bull 2004; 27: 422-425.

23. Fais A, Corda M, Era B, Fadda MB, Matos MJ, Quezada $Q E$, et al. Tyrosinase inhibitor activity of coumarinresveratrol hybrids. Molecules 2009; 14: 2514-2520.

24. Matos MJ, Santana L, Uriarte E, Delogu G, Corda M, Fadda MB, Era B, Fais $A$. New halogenated phenylcoumarins as tyrosinase inhibitors. Bioorg Med Chem Lett 2011; 21: 3342-3345.

25. Friedman M, Henika PR, Mandrell RE. Antibacterial activities of phenolic benzaldehydes and benzoic acids against Campylobacter jejuni, Escherichia coli, Listeria monocytogenes, and Salmonella enterica. J. Food Protect 2003; 66: 1811-1821.

26. Chang T-S. An updated review of tyrosinase inhibitors. Int J Molecular Sci 2009; 10 (6): 2440-2475.

27. Franco DCZ, Carvalho GSGd, Rocha PR, Teixeira RdS, Silva ADd, Raposo NRB. Inhibitory effects of resveratrol analogs on mushroom tyrosinase activity. Molecules 2012; 17: 11816-11825.

28. Bernard P, Berthon YJ. Resveratrol: an original mechanism on tyrosinase inhibition. International $J$ Cosmet Sci 2000, 22: 219-226.

29. Masamoto $Y$, Ando $H$, Murata $Y$, Shimoishi $Y$, Tada $M$, Takahata K. Mushroom tyrosinase inhibitory activity of esculetin isolated from seeds of Euphorbia lathyris $L$. Biosci Biotechnol Biochem 2003; 67(3): 631-634.

30. Jeong SH, Ryu YB, Long MJC, Ryu HW, Baek YS, Kang JE, Lee WS, Park KH. Tyrosinase inhibitory polyphenols from roots of Morus Ihou. J Agric Food Chem 2009; 57: 1195-1203. 
31. Mazimba O, Majinda RRT, Motlhanka D. Antioxidant and antibacterial constituents from Morus nigra. Afric $J$ Pharm Pharmacol 2011; 5(6): 751-754.

32. Kuete V, Fozing DC, Kapche WF, Mbaveng AT, Kuiate $J R$, Ngadjui BT, Abegaz BM. Antimicrobial activity of the methanolic extract and compounds from Morus mesozygia stem bark. J Ethnopharmacol 2009; 124(3): 551-555.

33. El-Falaha BM, Russell AD, Furr JR. Sensitivities of wildtype and envelope-defective strains of Escherichia coli and Pseudomonas aeruginosa to antibacterial agents. Microbios 1983; 38(152): 99-105.

34. Paulo LS, Ferreira S, Gallardo E, Queiroz JOAN, Domingues F. Antimicrobial activity and effects of resveratrol on human pathogenic bacteria. World $\mathrm{J}$ Microbiol Biotechnol 2010; 26: 1533-1538.

35. Kukric ZZ, Topalic-Trivunovic LN. Antibacterial activity of cis- and trans-resveratrol isolated from Polygonum cuspidatum rhizome. BIBLID 2006, 37:131-136.

36. Jung $H J$, Hwang IA, Sung WS, Kang $H$, Kang BS, Seu $Y B$, Lee DG. Fungicidal effect of resveratrol on human infectious fungi. Arch Pharmacal Res 2005; 28(5): 557560.

37. Rehman SU, Khan R, Bhat KA, Raja AF, Shawl AS, Alam MS. Isolation, characterisation and antibacterial activity studies of coumarins from Rhododendron lepidotum Wall. ex G. Don, Ericaceae. Braz J Pharmacogn 2010; 20(6):886-890 